\title{
The Evaluation of the Health Care Professionals' Knowledge, Prevention and the Perceptions on the Treatment of New Coronavirus (COVID-19)
}

\section{Sağlık Çalışanlarının Yeni Koronavirüs Enfeksiyonu (COViD-19) Hakkındaki Bilgi, Korunma ve Tedavi Algılarının Değerlendirilmesi}

\section{(i) Aydın BALCI, iD Şule ÇİLEKAR, ib İbrahim Güven COŞĞUN}

University of Health Sciences Afyonkarahisar Faculty of Medicine, Department of Chest Diseases, Afyon, Turkey

\begin{abstract}
Objective: The recent spread of new Coronavirus disease (COVID-19) pandemic which caused worldwide concern is a public health emergency situation. The risk of getting infected as well as the concern levels of the health professionals on this issue is very high due to their close contact with the infected patients. The aim of this study is to evaluate the concern level of being infected in the health professionals, as well as their view and perception of different applications used during the treatment of the COVID-19 cases together with their whole approach during this pandemic situation.
\end{abstract}

Methods: The study was conducted through an online survey that was sent to all the Health professionals of a pandemic hospital of a city in Turkey between 8 and 15 May 2020. This online survey was sent to all the professionals through social media platforms. The survey included both multiple-choice and true-false questions regarding COVID-19 diagnosis, clinical stage, treatment approach, concerns, knowledge, and awareness of the situation together with some social demographic characteristics of the health professionals. SPSS v20 program was used to evaluate the statistical analysis of the data collected. Data are shown through mean \pm and the standard deviation is shown through percentage.

Results: The study consisted of 250 (59.9\%) doctors and 169 $(41.1 \%)$ assistant healthcare professionals and the average age

\section{ÖZ}

Amaç: Yeni Coronavirüs hastalığı (COVİD-19) salgını, uluslararası endişe duyulan bir halk sağlığı acil durumudur. Bu çalışma, mevcut salgın sırasında sağlık çalışanları arasında enfekte olma endişesini, tutumlarını, tedavi ve COVİD-19 ile mücadeledeki çeşitli uygulama modifikasyonları konusundaki görüş ve davranış tarzlarını değerlendirmek amacıyla yapılmıştır.

Yöntemler: Türkiye'de bir ilin pandemi hastanesindeki sağlık personeline 8-15 Mayıs 2020 tarihleri arasında bir çevrimiçi anket uygulayarak gerçekleştirilmiştir. Ankette sosyodemografik özelliklere dair sorular ile beraber COVİD-19 tanı, klinik, tedavi tutumu, kaygı, bilgi ve farkındalık ile ilgili çoktan seçmeli sorular ve doğru yanlışs soruları soruldu.

Bulgular: Katılımcıların 250'si (\%59,9) doktor, 169'u (\%41,1) yardımcı sağlık personelinden oluşuyordu, yaş ortalamaları $33,21 \pm 6,88$ yıl idi. Sağlık sektöründe çalıştığı için COVİD-19 bulaşma riskinin yüksek olduğunu düşünenlerin ve kaygı duyanların sayısı ise $390(\% 93,1)$ kişidir. Yüz dokuz $(\% 26,01)$ kişinin yakınlarında COVID-19 testi pozitif çıktığı beyan edilmiştir. Altmış dört $(\% 15,3)$ sağlık çalışanı polimeraz zincir reaksiyonu (PCR) testi yaptırdığını bildirmiştir ve $3(\% 0,7)$ sağlık çalışanı da COVİD-19 PCR testin pozitif çıktığını bildirilmiştir.

Address for Correspondence: Aydın BALCl, University of Health Sciences Afyonkarahisar Faculty of Medicine, Department of Chest Diseases, Afyon, Turkey

E-mail: draydnbalc@gmail.com ORCID ID: orcid.org/0000-0002-6723-2418

Received: 09.07.2020

Cite this article as: Balcı A, Çilekar Ş, Coşğun iG. The Evaluation of the Health Care Professionals' Knowledge, Prevention and the Perceptions on the Treatment of New Coronavirus (COVID-19).. Bezmialem Science 2020;8(Supplement 2):27-35. 
of the participants was $33.21 \pm 6.88$ years. Seventy-six (18.1\%) of 128 people who smoked during the pandemic wanted to quit smoking. $390(93.1 \%)$ of the participants thought that they were in a high-risk group of being infected and were concerned about this matter. One hundred nine $(26.01 \%)$ of the participants had positive COVID-19 tests of their relatives or friends. Sixty-four (15.3\%) participants claimed to have a polymerase chain reaction (PCR) test, and $3(0.7 \%)$ of them reported that their COVID-19 PCR tests were positive. Eighty-four (20.04\%) stated that they used Hydroxychloroquine for prophylaxis.

Conclusion: The healthcare professionals working in the pandemic hospital during the pandemic stated that they generally had sufficient knowledge about COVID-19 and believed that our country would be successful with its fight against this pandemic. Moreover, our study proved the importance of knowledge levels in fighting communicable diseases.

Keywords: Health care professionals, knowledge levels of COVID-19, hydroxychloroquine prophylaxis
Sonuç: Salgın sırasında pandemi hastanesinde çalışan sağlıkçılar COVID-19 hakkında genel olarak yeterli bilgiye sahip olduklarını ve ülkemizin salgınla mücadelede başarılı olacağına inandıklarını ortaya koymuştur.

Anahtar Sözcükler: COVID-19, sağlık çalışanları COVID-19 bilgi düzeyi, hidroksiklorakin proflaksisi

\section{Introduction}

A new type of Coronavirus disease (COVID-19) that had negative effects in all parts of daily life emerged in China (1). The first cases of the pandemic started as a disease without any etiology at the end of December 2019 in the city of Wuhan, which is located in the Hubei province of China (2). The World Health Organization (WHO) declared the disease as a public health pandemic and an international state of emergency on 30 January 2020 when it already spread to 34 different districts of China up to that date (3).

Structurally COVID-19 is a positive polarity ss-RNA enveloped virus which is approximately 350-kilo base pair (kbp) in size (4). The droplet feature was identified as the primary cause of the spread of the COVID-19 virus (5).

Incubation period, which is the time until the symptoms develop after being exposed to the virus, is between 2 and 14 days with an average of 5 days (6). Upper respiratory tract infections, high fever, dry cough, difficulty in breathing, myalgia, pain in throat, nausea, vomiting, and diarrhea are some of the common symptoms of the infection (7). When the vital role of the immune system of the body is considered, the risk of elderly people and people with chronic diseases that weakens the immune system for being infected with the virus is much higher when compared to young and healthy people with stronger immune systems (8). The COVID-19 infection might result in acute coronary syndrome, acute respiratory failure, and fatality in serious cases (9). Even though the fatality rate associated with COVID-19 is quite low, it has the potential of spreading very quickly (10). It is strongly recommended to place the possibly infected individuals into quarantine and observation after realtime RT-PCR samples were taken until further investigations were carried out (11). Unfortunately, there is no antiviral vaccine that has been developed at the moment. Therefore, patients have to rely on supportive treatments like vitamins A, C, and D (12).
There are also different opinions from the current data on the use of certain antimalarial drugs, such as chloroquine (CQ) and hydroxychloroquine (HCQ) that have been tried for the treatment of COVID-19 for chemoprophylaxis as well as continuing to use the barrier system (13). Some of the authors decided on the use of CQ and HCQ for the prophylaxis against COVID-19 based on the results of In vitro studies. Moreover, in line with these results, the China's National Health Commission Guidelines for COVID-19 and U.S. Food and Drug Administration recommended the use of HCQ on the treatment of COVID-19 despite its indefinite benefits and opened the way for its use for prophylaxis purposes $(14,15)$.

Due to COVID-19's fast-spreading and devastating attitude, a lot of countries shut down education institutions, social gatherings, sports events, airports, and even banks or brought flexible working hours for them to be able to prevent the spread of the virus. Besides most of the individuals played their parts in the society quarantining themselves by staying inside their homes to minimize the spread of the virus. Additionally, having all the hospitals functioning actively during these difficult times is vitally important and they are rarely shut down during pandemic conditions (16). The health care professionals are at high risk of contamination due to their close contact with the infected patients. Therefore, there is a high risk of health care professionals getting infected from their patients and potentially they can spread the virus to their friends, relatives, and even to other patients. Under these circumstances, the development of anxiety to get infected from the patients of health care professionals might be considered a natural behavior (16).

Even though the Ministry of Health issued guideline on prevention, most of the health care professionals are scared of conducting detailed examination and treatment for the patients with COVID-19 risk. Actually health care professionals might not be updated with the latest guidelines. Because of this, we conducted a survey-based study that aimed to evaluate the 
knowledge levels of the health care professionals working actively during the COVID-19 pandemic on the infection as well as their behaviors and attitudes, knowledge level on the treatment process, and the methods they used personally for prophylaxis in our city.

\section{Method}

An online survey with 39 questions was used in this study between 8 and 15 May 2020 with a group of doctors and nurses working in the units related to COVID-19 from a total of 965 health professionals of a pandemic hospital of a city in Turkey. For this purpose, we designed a comprehensive survey on https://docs. google.com/forms website. The survey was sent out through the Whatsapp application to the professionals whom we contacted through phone calls personally to brief them about the content of the survey and the responses to the questions were recorded after their consent was obtained. The survey was completed manually by the professionals that could not be contacted through social media. The health professionals involved in the diagnosis, treatment and the follow-up process of COVID-19 were included in the study.

\section{Survey Design}

Demographic parameters of the participants including age, gender, marital status, profession, and smoking habits were recorded. The professions and titles of the participants were categorized. We asked the participants to fill the survey with 39 questions that aimed to evaluate their knowledge of COVID-19 symptoms, diagnosis and treatment, blood table, risk groups, ways of transmission, precautions, and the prevention methods, level of contact with the infection, prophylaxis, and concerns. The answers to the questions were in the format of Present-not Present, Yes-No, True-False- Do not know, Agree-Disagree- Not sure, multiple choices, and open-ended answers.

SPSS v20 program was used for the statistical analysis of the data which were transferred to Microsoft Excel from the Google form format by adhering to the original states of surveys. Data were shown as mean \pm standard deviation, number of individuals, and percentage. The suitability of the quantitative data for normal distribution was tested by the Kolmogorov-Smirnov, ShapiroWilk test and graphical evaluations. Student's t-test was used for comparison of two groups of quantitative data with normal distribution, and the Mann-Whitney $U$ test was used for comparison of two groups of data with non-normal distribution. Pearson Chi-Square test and Fisher's Exact test were used to compare qualitative data. Significance was set at $\mathrm{p}<0.05$.

\section{Ethics Committee Approval}

Afyonkarahisar Health Sciences University Ethical Committee approval with 2020/119 number and 2011-KAEK-2 code was obtained.

\section{Results}

Our study included $419(\% 43,41)$ health professionals out of 965(300 doctors, 515 nurses, 150 health technicians) health care professionals of our hospital, who were involved in diagnosis, treatment, and follow up processes of the COVID-19.

When the demographic characteristics of the participants were evaluated, 232(\%55,4) of them were males and $187(44.6 \%)$ of them were females with a mean age of $33.21 \pm 6.88$ (20-57) years. The number of participants having at least one child or more was 276 . There were slightly more $250(59,9 \%)$ doctors than the 169 nurses $(41.1 \%)$ (Table 1$)$.

The number of the participants with chronic diseases was 67 (16\%), of which $17(4.05 \%)$ had asthma, $13(3.1 \%)$ had a functional thyroid disorder, $8(\% 1,9)$ had diabetes mellitus and $8(\% 1,9)$ had high blood pressure. There was no statistically significant difference between the profession and gender respectively in the presence of chronic disease $(\mathrm{p}=0.354,0.239)$.

There was no significant difference in smoking habits according to the professions ( $\mathrm{p}=0.973)$. A total of $128(30.5 \%)$ participants smoked with an average of 23.2 packets of cigarettes per year. The total number of smoking participants who either wanted to quit or made an attempt to quit during the COVID-19 was $76(18.1 \%)$ and there was a statistical similarity between the profession groups.

Almost all the participants (94.7\%) claimed to know the means of the transmission of COVID-19. Also, nearly all of them (98.1\%) responded with the answer of "yes" to the question on if they knew the general symptoms of the disease and the necessary prevention methods towards the infection.

Total of $151(36 \%)$ participants [(79 (18\%) doctors, $79(18 \%)$ nurses)] claimed sensitivity towards cold and flu-like illnesses; therefore, they stated that they were scared of being infected with the COVID-19 and it showed statistical significance among the nurses $(\mathrm{p}<0.001)$. There was a similar perception between both professions ( $\mathrm{p}=0.209$ ) as 151 nurses and 239 doctors considered

\begin{tabular}{|c|c|c|c|}
\hline \multicolumn{4}{|c|}{$\begin{array}{l}\text { Table 1. Socio-demographic characteristics of the } \\
\text { participants }\end{array}$} \\
\hline & & $\mathrm{n}$ & $\%$ \\
\hline Mean age & $\begin{array}{l}33.21 \pm 6.88 \\
\text { Male }\end{array}$ & 232 & 55.4 \\
\hline \multirow[t]{5}{*}{ Gender } & Female & 187 & 44.6 \\
\hline & Total & 419 & 100 \\
\hline & Research Assistant Doctor & 124 & 29.6 \\
\hline & Assistant Professor & 106 & 25.3 \\
\hline & Associate Professor & 10 & 2.4 \\
\hline \multirow{5}{*}{ Occupation } & Professor & 10 & 2.4 \\
\hline & Assistant Health Personnel & 169 & 40.3 \\
\hline & Total & 419 & 100 \\
\hline & Married & 280 & 66.8 \\
\hline & Single & 128 & 30.5 \\
\hline \multirow[t]{2}{*}{ Marital status } & Divorced & 11 & 2.6 \\
\hline & Total & 419 & 100 \\
\hline
\end{tabular}


themselves at high-risk groups for the transmission of the virus because they worked in the healthcare sector.

When the responses to the question on the knowledge level of them regarding the SARS-CoV-2 and its virus family were evaluated, 119 (42.2\%) nurses and 163 (57.8\%) doctors gave the correct answer of "a virus with positive polarity enveloped onto RNA". The correct response rate to this question showed statistical significance among the doctors $(\mathrm{p}=0.021)$. Almost all the participants, 418 (99.8\%), selected "China" as the emerging country of the virus. Total of 397 (94.7\%) participants, of which $148(35.3 \%)$ were nurses and 249 (59.4\%) were doctors, selected the correct answer of "droplet infection" choice as the primary means of transmission of COVID-19 infection and there was a statistical difference among the doctors $(\mathrm{p}=0.002)$.

Total of 227 (54.2\%) participants, of which 39 (9.3\%) were nurses and $188(44.9 \%)$ were doctors, selected "polymerase chain reaction" as a mean of final diagnosis of the virus and this was statistically significant $(\mathrm{p}<0.001)$. On the other hand, a total of 105 (25\%), of which 58 (13.9\%) were nurses and 47 (11.1\%) were doctors, selected "Thorax BT together with polymerase chain reaction" choice.

"Oropharyngeal sampling" was selected as an answer by 194 $(46.3 \%)$ of them for the question on sampling method which had the highest value for the diagnosis of the COVID-19 while $183(43.7 \%)$ of them selected correct answer of "bronchoscopy sampling" which was mainly from the doctors of 157 (37.5\%) and it showed a statistical difference $(\mathrm{p}<0,001)$.
Total of $241(57.5 \%)$ participants, of which $49(11.7 \%)$ were nurses and 192 (45.8\%) were doctors, gave the correct answer of "lymphopenia" to the question regarding the hemogram table inside the blood during COVID-19 and this showed statistical difference for the doctors $(\mathrm{p}<0.001)$. The answers of the participants to the question on procalcitonin levels when there was no accompanying bacterial infection were as followed; $168(40.1 \%)$ of them "does not change', 114 (27.2\%) of them "will increase", 109 (26\%) of them "will decrease" and 28(\%6, 7) of them did not answer at all. Most of the correct answer [129 (30.8)] of "does not change" came from the doctors and this showed a statistical difference with nurses $(\mathrm{p}<0.001)$.

Total of 149 (35.6\%) participants gave the answer of "fever, dry cough, and fatigue"; on the other hand, 62 (14.8\%) of them gave the answer of "fever, dry cough and loss of sense of taste and smell" to the question on the most common clinical sign and symptoms of COVID-19.

The answer of "75 mL/min" was chosen by $152(36.3 \%)$ of the participants to the question on the threshold saturation value of the patients with respiratory difficulties for the intubation procedure and $141(33.7 \%)$ of them gave the answer of " $80 \mathrm{~mL} /$ min”.

A total of 208 (82.5\%) doctors answered "Yes" when they were asked if they changed their approach to the usage of non-steroid anti-inflammatory medicines towards paracetamol like medicines during COVID-19.

Table 2. Knowledge about COVID-19 among health care workers

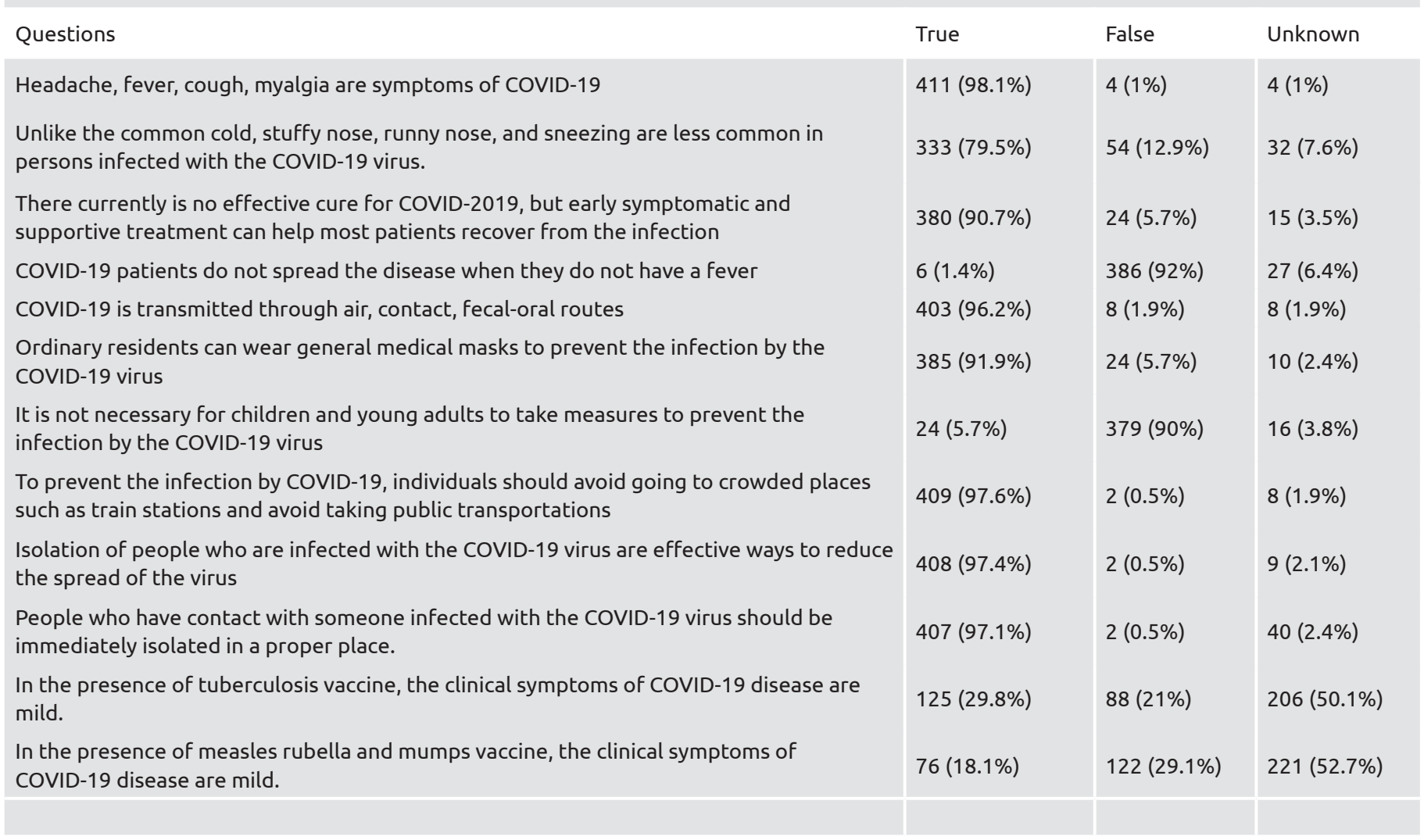


When the responses to 15 questions, which were designed in True-False- Do not Know format, on the means of transmission of the coronavirus and the anxiety towards the virus, 371 (88.5\%) of the participants believed that the severity of the disease was correlated with obesity, chronic diseases, and the old age. Also, 409 (97.6\%) of the participants believed in avoiding public transport and crowded places and the necessity of following the social distancing rules. Additionally, 164 (39.1\%) of the participants believed that consuming wild animals would lead to the transmission of the virus. Responses to the other 12 questions of the 15-question parts were shown in Table 2.

Total of $122(29.1 \%)$ participants stated that they did not have any contact with anyone with the COVID-19 infection and 96 $(22.9 \%)$ of those with the contact stated that these patients were in their units they were working, when they were asked about the level of contact of the participants with the COVID-19 cases.

When asked if any of the relatives and friends were diagnosed with COVID-19, 121 (29.2\%) participants, of which 82 $(19.8 \%)$ were doctors and 39 (9.4\%) were nurses, had friends and relatives who had their COVID-19 tests with a positive result and this showed statistical significance for the doctors $(\mathrm{p}=0.024)$.

When they were asked if they either had COVID-19 PCR or fast antigen-antibody tests, a total of $64(\% 15,3)$ of them, of which $21(5 \%)$ were nurses and $43(10.3 \%)$ were doctors, answered "yes" ( $\mathrm{p}=0.267) .2(0.4 \%)$ doctors and $1(0.3 \%)$ nurse stated that their own COVID-19 PCR test results were positive.
When evaluating the precautions and the preventions against COVID-19 of the health care professionals, 387 (91.7\%) of them stated that they washed their hands with soap for at least 20 seconds, followed the social distancing rules keeping the barrier measure. Table 3 shows the answers to the most common preventive measures taken by the health care professionals against the COVID-19.

A total of 158 (37.7\%) participants believed that using hydroxychloroquine (plequanil) might be beneficial for prophylaxis; however, 151 (36\%) of them believed that there was not enough evidence to support the usage of it. 90 (21.5\%) of them stated that their doctor friends recommended, 85 $(20.3 \%)$ of them stated that they used the literature as reference, $66(15.8 \%)$ of them referred to the panels conducted by the specialists and $36(8.6 \%)$ of them referred to media when they were asked about the source of information on the effect of hydroxychloroquine for prophylaxis.

Total of $84(20.04 \%)$ participants, of which 28 (6.7\%) were nurses and $56(13.4 \%)$ were doctors, stated that they used hydroxychloroquine for prophylaxis to protect themselves from the COVID-19 ( $\mathrm{p}=0.213) .3$ of these 84 participants stated that they used hydroxychloroquine for prophylaxis in line with the Ministry of Health's high-risk contact criteria due to their contact with the COVID-19 infected patients. The dosage and the frequency of hydroxychloroquine usage for prophylaxis are shown in Table 4.

Table 3. Precautions against virus transmission

\section{Questions}

I don't leave the house unless it is necessary

I wash my hands with soap for at least 20 seconds during the day

I wear a mask if I have to go out

I pay attention to social distance

I do not approach people more than 1 meter in crowded environments

\section{Answers}

n \%

$\begin{array}{ll}379 & (89.8 \%) \\ 387 & (91.7 \%) \\ 383 & (90.8 \%) \\ 385 & (91.2 \%) \\ 383 & (90.8 \%)\end{array}$

Table 4. The use of hydroxychloracine in prophylaxis

\begin{tabular}{|l|l|l|}
\hline How to use hydroxychloroquine & n & $\%$ \\
\hline Twice a week, one & 31 & 7.2 \\
\hline One in twenty-one days & 25 & 6.0 \\
\hline One every day & 10 & 2.4 \\
\hline Once every two weeks & 6 & 1.4 \\
\hline Two days three times during my contact with patients & 6 & 1.4 \\
\hline Once a week & 2 & 0.5 \\
\hline I used a total of three doses & 2 & 0.5 \\
\hline Once a week, two doses & 1 & 0.2 \\
\hline I use it because of rheumatism & 1 & 0.2 \\
\hline Total & 1 & 20.04 \\
\hline
\end{tabular}




\section{Discussion}

Our study shows that most of the health care professionals of a pandemic hospital in one of the cities of Turkey have comprehensive knowledge about the COVID-19 disease and they follow the relevant algorithms with necessary literature references. Almost all the participants (94.7\%) are confident with their knowledge on the means of transmission of the virus and with their knowledge on the general symptoms (98.1\%) as well as how to protect themselves from the virus. Similarly, 93.1\% of the participants believe that they are in a high-risk group for the infection and $82.3 \%$ of them believe that our country will be successful with its fight against the infection.

Our study used a survey, which was developed by us, mainly focusing on closed-end questions to collect information on health care professionals' knowledge level of COVID-19, their behaviors and attitudes towards the treatment process, their concerns together with preventive measures taken during the COVID-19. It is proven that studies, which are based on surveys, collect information about preferences, attitudes, perceptions, and the experiences of the participants. However, careful data collection and interpretation are required [17].

The common symptoms of this COVID-19 disease include fever, dry cough, and difficulty in breathing. Myalgia, developing phlegm and sore throat are the other symptoms that are less common (7). Virus is transmitted among the humans through droplets which happen to be due to cough. Touching at its own face after touching a contaminated area is believed to be another means of transmission of the virus $(18,19)$. The incubation period which is the time until the symptoms develop after exposure to the virus is between 2 and 14 days with an average of 5 days (6). The standard diagnostic method is to conduct real-time reverse transcriptase-polymerase chain reaction (rRT-PCR) tests with a nasopharyngeal swab taken from the individual (20). Diagnosis of the infection can be done by evaluating the symptoms, risk factors and computerized chest tomography scans pointing to pneumonia together (21). The answers which are similar to the literature regarding most of the basic knowledge about the COVID-19 were obtained in our study and nearly all the participants gave correct answers to the questions.

Due to long incubation (up to 14 days) period of SARS-CoV-2, it is nearly impossible to determine the individual's exposure to the virus during different stages like isolation, quarantine, and till the mortality stage. Because of this, very fast pace transmission of COVID-19, which impacted millions of people around the world, is causing severe physiological stress and fear among the people (22). Additionally, the non-availability of an approved treatment or prophylaxis vaccine treatment increases the anxiety of being infected. Therefore, health care professionals are at high risk of being exposed to the virus during this COVID-19 pandemic and this leads to a great level of fear and anxiety among them (23). Most of our participants had the fear factor and there were statistical similarities between the doctors and the nurses on this issue $(\mathrm{p}=0.209)$.
Primary transmission means of the COVID-19 infection happens through droplets (5). That is why the likelihood of health care professionals being infected and spreading the virus further increases. The current study shows that healthcare professionals' anxiety of getting infected through their colleagues is similar to the anxiety they have by getting infected in society which has a very fast pace of the spread of the virus among the people (24). One of the other concerns that the health professionals have is transmitting the virus to their family members after they have completed their work. Coronavirus may be alive on some surfaces from a few hours to few days and due to the long incubation period of the virus, people will not show any symptoms and healthcare professionals are scared of being infected from these people who are admitted to the hospital for other reasons than COVID-19 (25). During the outbreak of COVID-19, the importance of hand hygiene was emphasized repeatedly and this issue is even more important for health care professionals. The studies show that washing hands with soap and water or cleaning them with alcohol-based disinfectants is an important precaution to control the spread of respiratory diseases including SARS $(26,27)$. Because of this, WHO suggests washing the hands or using alcohol-based disinfectants very frequently during the health care procedures? The use of a particulate respiratory device like an N-95 mask was recommended for the treatment of patients with the suspicion of COVID-19. Otherwise, when the distance is less than 1 meter between the professional and the patient, at least a surgical mask should be used to treat all the patients (5). Most of the participants (93.6\%) of our study believe that they have a higher risk of getting infected than other people and they are worried about this. Besides, without any statistical difference between the doctors and the nurses, 385 (91.5\%) of the participants were observed adhering to the preventive measures. Participants of our study were observed following the literature for the updates, adhering to social distance rules as well as paying attention to the usage of masks. They also stated that they adhere to the social distancing and hygiene rules among each other and at their homes. Statistically, doctors gave more correct answers to the questions on the means of transmission, how to make the diagnosis, and the best sampling method which had the highest value for the diagnosis of the COVID-19 ( $<<0.001)$. This might be related to the fact that doctors are in the front line of the first diagnosis and the treatment phase of the disease while the nurses are responsible for the follow-up and the treatment of the hospitalized patients.

The study of Ling Hu et al. (28) shows an increase of COVID-19 risk with the presence of chronic diseases and smoking. In parallel to that study, $76(18.13 \%)$ of 128 smoking participants of our study tried to quit smoking because they were worried about getting infected with COVID-19. Also, \%88. 5 of the participants stated that the elderly, obese, and people with chronic diseases have a higher possibility of severe cases of COVID-19.

How to provide the most effective ventilator support to the COVID-19 patients with respiratory insufficiency is still being investigated. Apart from intubation, high flow nasal cannula 
and positive airway pressure methods can be used. These two methods provide similar benefits with intubation to the patients at critical stages of the disease; therefore, there is nothing certain about in which situation intubation should be done (29). A total of $170(40.57 \%)$ participants of our study believe that intubation should be performed if the saturation that is measured from the finger falls below $75 \mathrm{~mL} / \mathrm{min}$. Additionally, 258 (61.6\%) of the participants believe that providing non-invasive mechanical ventilation through a helmet mask with two hoses before the intubation might provide better results if there are suitable ICU conditions before the intubation process.

Because of the high fever symptoms of COVID-19, feverreducing therapies should be conducted and non-steroid antiinflammatory medicines and paracetamol like medicines are considered to be the primary resources. The study of Sridharan GT et al. (30) shows that the usage of Ibuprofen and other non-steroid anti-inflammatory medicines increased the risk of deterioration of COVID-19 infection. \%82,5 of the doctors who follow this study and similar studies in the literature state in our study that they choose paracetamol like medicines.

The study of Schuetz at al. (31) determined that there was a correlation between the procalcitonin level elevation and the severity of the bacterial infections and it was blunted during the viral infections. In our study, 168 (40.1\%) participants selected "does not change" where 114 (27.2\%) of them selected "will increase" and 109 (26\%) of them "will decrease" as an answer to the question on the procalcitonin level due to the fact that COVID-19 is a viral infection. Most of the correct answer, 129 (30.8\%), of "does not change" came from the doctors and this shows a statistical difference with nurses $(p<0.001)$ which might be related to the fact that the doctors are the ones dealing with the laboratory results to define the treatment process.

Although there is no definite treatment for COVID-19, hydroxychloroquine, and chloroquine which are antimalarial agents with immunomodulator and anti-inflamatuar activities are recommended for possible treatments of COVID-19 (32). Even though there is no evidence or data to support the use of these medicines as a preventive treatment, there is a lot of interest among the people who are not infected but with a high risk of being infected to use these medicines as prophylaxis (33). Some of the authors decided on the use of CQ and HCQ for the prophylaxis against COVID-19 based on the results of In vitro studies. Moreover, in line with these results, China's National Health Commission Guidelines for COVID-19 and U.S. Food and Drug Administration recommended the use of HCQ on the treatment of COVID-19 despite its indefinite benefits and opened the way for its use for prophylaxis purposes $(14,15)$. Our study also shows that a total of $84(20.04 \%)$ participants, of which $28(6.7 \%)$ were nurses and $56(13.4 \%)$ were doctors, stated that they believed in the benefits of hydroxychloroquine for prophylaxis and started taking at different doses based on their individual choices. $(\mathrm{p}=0.213)$. Our study also shows that the doctors were at least $8 \% 0$ aware of most of the current studies conducted as well as the experimental treatments.

\section{Study Limitations}

Some of the limitations of the study as follows: The data of the study were collected in a very short period due to the fast impact of the health care professional on the diagnosis, treatment, and the preventive measure of COVID-19. Also, the knowledge level of the health care professionals on COVID-19 treatment shows differences due to different studies emerging every day on the subject due to its dynamic status. Moreover, the study was conducted only in a pandemic hospital in a city. Even though the survey was applied to almost all the doctors and to nurses working inside the COVID-19 units or having interaction with the patients, lack of response to the surveys and the small sample size was another constrain. Further studies should be done with bigger sample sizes and the data of the studies should be interpreted carefully. Even though the survey was sent out to all the health care professionals, the target group of the study was the doctors.

\section{Conclusion}

There was not any study conducted in our country before this study evaluating the knowledge level, fear and anxiety, attitude to treatment, and the approach to prophylaxis to COVID-19 of the health care professionals. Even though health care professionals have a high level of knowledge and application standards, they have the responsibility to keep themselves up to date with all the new information and treatment procedures of COVID-19 emerging due to its pandemic status. Only a small number of doctors prefer to use hydroxychloroquine for prophylaxis as it only has hypothetical recommendations of its usage on COVID-19 which does not have an approved treatment method yet.

Health care professionals have a special role in the management of this crisis situation as a part of the Covid-19 pandemic. They keep up with the current literature updates related to COVID-19 which shows how much attention the health care professionals give to the current situation of the COVID-19 pandemic. They stated their sensitivity to preventive measures as they consider themselves in a high-risk group to get infected with the virus. It shows that more than $\% 90$ of the health care professionals in the pandemic hospital have a sufficient level of knowledge on COVID-19 and they believe that as a country, we will be successful against the fight with the COVID-19 pandemic. This study also proved the importance of knowledge level as a key factor in the management of communicable diseases. The fact that they know that they are in a high-risk group for the transmission of COVID-19 and that even more than half of them have the history of either direct or indirect contact with COVID-19 patients, the belief that this pandemic will be managed successfully might be related to the high level of education and the knowledge. 


\section{Ethics}

Ethics Committee Approval: Afyonkarahisar University of Health Sciences, Faculty of Medicine, Department of Chest Diseases 05.05.2020.

Peer-review: Externally and internally peer reviewed.

\section{Authorship Contributions}

Concept: , Design: , Data Collection or Processing: , Analysis or Interpretation: , Literature Search: , Writing:

Conflict of Interest: No conflict of interest was declared by the authors.

Financial Disclosure: The authors declared that this study received no financial support.

\section{References}

1. Gralinski LE, Menachery VD, Return of the cCoronavirus: 2019nCoV. Viruses 2020;12:135

2. Nishiura, H. Transition Coverage of New Coronavirus in Wuhan. J Clin Med 2020;9:330.

3. Mahase, E. China coronavirus: WHO declares international emergency as death toll exceeds 200. BMJ Clin Res 2020;368:M408.

4. Chen Y, Liu Q, Guo D. Emerging coronaviruses: Genome structure, replication, and pathogenesis J Med Virol 2020;92:418-23.

5. Ge, Z .; Yang, L .; Xia, J .; Fu, X .; Zhang, Y. COVID-19'un olası aerosol iletimi ve diş hekimliğinde özel önlemler. J. Zhejiang Üniv. B 2020 , 1-8. [ Google Akademik ] [ CrossRef]

6. Velavan TP, Meyer CG The COVID-19 epidemic. Trop Med Int Health 2020;25:278-80. doi:10.1111/tmi.13383.

7. Chen, N. Wuhan, Çin'de 2019 yeni koronavirüs pnömonisinin 99 vakasının epidemiyolojik ve klinik özellikleri: Tanımlayıcı bir çalışma. Lancet 2020 , 395 , 507-513. [ Google Akademik ] [ CrossRef ]

8. Wu, P .; Hao, X .; Lau, EHY; Wong, JY; Leung, KSM; Wu, JT; Cowling, BJ; Leung, GM 22 Ocak 2020'de Çin, Wuhan'da yeni koronavirüs enfeksiyonlarının epidemiyolojik özelliklerinin gerçek zamanlı geçici değerlendirmesi. Euro Surveill. 2020 , 25 , 1-6. [ Google Akademik ] [ CrossRef] [ PubMed ]

9. Holshue, ML Amerika Birleşik Devletleri'nde 2019 Roman Coronavirüs'ün İlk Örneği. N. Engl. J. Med. 2020 . [ Google Akademik ] [ CrossRef] [ PubMed ]

10. Chen, J. Pathogenicity and transmissibility of 2019-nCoV - a quick overview and comparison with other emerging viruses. Microb Infect 2020;22:69-71.

11. Corman VM, Landt O, Kaiser M, Molenkamp R, Meijer A, Chu DK, et al. Detection of 2019 novel coronavirus (2019-nCoV) by real-time RT-PCR . Euro Surveill 2020;25:1-8.

12. Zhang L, Liu Y. Potential interventions for novel coronavirus in China: A systematic review . J Med Virol 2020;92:479-90.

13. Gao J, Tian Z, Yang X. Breakthrough: chloroquine phosphate has shown apparent efficacy in treatment of COVID-19 associated pneumonia in clinical studies. Biosci Trends. 2020;14:72-3.
14. Department of Infectious Diseases, Central Hospital of Ezhou, Ezhou, Hubei, China

15. Department of Cardiovascular Medicine, Yunmeng People's Hospital, Xiaogan, Hubei, China

16. Ather A, Patel B, Ruparel NB, Diogenler A. Hargreaves KM. Coronavirus disease 19 (COVID-19): implications for clinical dental care. J Endod. 2020;46:584-95.

17. Lydeard, S. Bir araştırma aracı olarak anket. Dostum. Pract. 1991, 8 , 84-91. [ Google Akademik ] [ CrossRef]

18. Neher RA, Dyrdak R, Druelle V, Hodcroft EB, Albert J. Potential impact of seasonal forcing on a SARS-CoV-2 pandemic. Swiss Med Wkly 2020;150:w20224.

19. Peng X, Xu X, Li Y, Cheng, Zhou X, Ren,B. Transmission routes of 2019-nCoV and controls in dental practice. Int J Oral Sci 2020;12:16.

20. "2019 Novel Coronavirus (2019-nCoV) Situation Summary”. Centers for Disease Control and Prevention

21. Jin YH, Cai L, Cheng ZS, Cheng H, Deng T, Fan YP, et al. A rapid advice guideline for the diagnosis and treatment of 2019 novel coronavirus (2019-nCoV) infected pneumonia (standard version) Mil Med Res 2020:7:4. https://doi.org/10.1186/s40779-020-0233-6

22. Moorthy, V .; Restrepo, AMH; Preziosi, MP; Swaminathan, S. Aktif karantina önlemleri COVID-19'un ölüm oranını azaltmanın başlıca yoludur. Boğa. Dünya Sağlık Organ. 2020 , 98 , 150. [ Google Akademik ] [ CrossRef ]

23. Lai J, Ma S, Wang Y, Cai Z, Hu J, Wei N, et al. Factors associated with mental health outcomes among health care workers exposed to coronavirus disease 2019 JAMA Netw Open 2020;3:e203976.

24. Person B, Sy F, Holton K, Govert B, Liang A, Garza B, et al. Fear and Stigma: The Epidemic within the SARS Outbreak . Emerg. Infect. Dis. 2004; 10:358-63.

25. van Doremalen N, Bushmaker T, Morris DH, Holbrook MG, Kumar A, Williamson BN, et al. Aerosol and surface stability of SARS-CoV-2 as compared with SARS-CoV-1. N Engl J Med 2020; 382:1564-7.

26. Mantar IC-H, Cairncross S. Effectiveness of hand washing in preventing SARS: A review. Trop Med Int Health 2006:1749-58.

27. Jefferson T, Foxlee R, Mar CD, Dooley L, Ferroni E, Hewak B, et al. Physical interventions to interrupt or reduce the spread of respiratory viruses. Cochrane Database Syst Rev 2011:CD006207.

28. Hu L, Chen S, Fu Y, Gao Z, Long H, Wang JM, et al. Risk factors associated with clinical outcomes in 323 COVID-19 hospitalized patients in Wuhan, China. Clin Infect Dis ciaa539, https://doi. org/10.1093/cid/ciaa539.

29. Murthy S, Gomersall CD, Fowler RA . "Care for Critically Ill Patients With COVID-19”. JAMA. doi:10.1001/jama.2020.3633. PMID 32159735.

30. Sridharan KG, Gurusaravanan K, Kotagiri R, Chandiramani HV, Mohan BP, Vegunta R, et al. COVID-19 and Avoiding Ibuprofen. How Good Is the Evidence? Am J Ther 2020;27:e400-2. 
31. Schuetz P, Albrich W, Mueller B. Procalcitonin for diagnosis of infection and guide to antibiotic decisions: past, present and future. BMC Med 2011;9:107.
32. Baden LR , Rubin EJ. Covid-19 - the search for effective therapy N Engl J Med 2020;382:1851-2 10.1056 / NEJMe2005477. 